\title{
Türkçede $\{-\mathrm{gA} / \mathrm{I} \boldsymbol{\}}\}$ ve $\{-(\mathrm{I} / \mathrm{A}) \boldsymbol{c}\}$ Biçimbirimleri: Türetkenlik Çerçevesinde Eşsüremli Bir Çalışma
}

\author{
Özge Can ${ }^{1}$, Demet Kayabaşı ${ }^{2}$ \\ ${ }^{1,2}$ Dokuz Eylül Üniversitesi Edebiyat Fakültesi Dilbilim Bölümü, Tınaztepe Yerleşkesi \\ 35390 Buca /Izmir \\ ${ }^{1}$ ozge.can@deu.edu.tr, ${ }^{2}$ demettkayabasi@gmail.com
}

(Gönderilme tarihi 3 Ağustos 2015; kabul edilme tarihi 30 Mayls 2016)

\begin{abstract}
ÖZ: Türetim süreçleri hem birbirlerine, hem de dillere göre türetim alanı ve sıklığı açısından farklılık göstermekte bu farklılık sözcük türetme sürecinin ne kadar işlek olduğunu ortaya koymaktadır; ancak, türetkenlik derecesi türetken olma ve olmama arasındaki açık biçimde tanımlanmış bir sınıra değil, bir derecelendirmeye dayandırılmaktadır (Uzun, 2006, s. 90). Çalışmamızın çıkış noktası BİLGİÇ, ÇALGIÇ ve YARGIÇ sözcükbirimlerinde açı bir taban ayrımı yapılamamasıdır. Bu sorunun çözümlenebilmesi için $\{-\mathrm{gA} / \mathrm{Iç}\}$ ve $\{-$ $(\mathrm{I} / \mathrm{A}) c ̧\}$ biçimbirimlerinin birbirlerine göre türetkenlik derecelerinin ve türetkenlik alanlarını saptanması gerekliliği doğmuştur. Çalışmamızda söz konusu biçimbirimlerin türetim alanlarının ne olduğu, birbirlerine göre türetkenlik dereceleri, iç içe incelenip incelenmemeleri gerektiği ve çalışmamızın çıkış noktasını oluşturan sözcükbirimlerin taban ayrımının nasıl yapılacağı Dil Derneği'nin (2012) Türkçe Sözlük'ü olarak belirlenen veri tabanı çerçevesinde incelenmiş ve elde edilen veriler tartışılmıştır. Çalışmamızda, saptanan yeni bulguların yanı sıra, alanyazındaki bulguların geçerliliğinin sınanması ve alanayazına katkıda bulunulması amaçlanmıştır.

Anahtar Sözcükler: türetim, türetkenlik derecesi, türetkenlik ölçeği, Türkçede türetim, türetim biçimbirimleri
\end{abstract}

\section{The $\{-\mathrm{gA} / \mathrm{I}\}\}$ and $\{-(\mathrm{I} / \mathrm{A}) \mathrm{c}\}$ Morphemes in Turkish: A Synchronic Approach to Derivation}

ABSTRACT: Derivation processes show a high degree of variation from one language to another and in terms of the range of derivation and frequency of use. This variation indicates that derivation is a productive process, which seems to form a continuum rather than a dichotomy between productivity and unproductivity (Uzun, 2006, p. 90). This study started as a result of our observation that a certain base cannot be clearly identified in the following lexemes: BİLGİÇ, ÇALGIÇ and YARGIÇ. In order to eliminate this uncertainty, it is necessary to determine the range and the frequency of the derivations obtained by the $\{-\mathrm{gA} / \mathrm{I}\}\}$ and $\{-(\mathrm{I} / \mathrm{A}) \mathrm{c}\}$ morphemes. To this end, we examined the range of the derivations based on these morphemes and investigated their degree of productivity with respect to one another. We also aimed to answer the question whether one of the morphemes can be treated as the other's allomorph and discussed the ways in which the base of the problematic lexemes in question can be determined. Our data were the list of 
lexemes derived by $\{-\mathrm{gA} / \mathrm{I} c ̧\}$ and $\{-(\mathrm{I} / \mathrm{A}) \mathrm{c}\}$ listed in the Turkish Dictionary by Dil Derneği (2002). We discussed the data, compared the findings in the literature with the new data we presented, and thus aimed to contribute to the existing literature.

Keywords: derivation, degree of productivity, productivity scale, derivation in Turkish, derivational morphemes

\section{Giriş}

Dile yeni bir sözcük ekleme işlemi olarak tanımlanabilecek türetimin dilbilgisel yapı içinde bir kurallar bütünü mü yoksa bir örüntü olarak mı ele alınması gerektiği pek çok araştırmacı tarafindan tartışılmış ve türetim süreçlerinin işlerlik derecesi hakkında farklı yaklaşımlar öne sürülmüştür. Türetim süreçleri, hem birbirlerine hem de dillere göre türetim alan ve sıklıkları açısından farklılık göstermektedir. Bu farklılık sözcük türetme sürecinin ne kadar türetken ve ne kadar işlek olduğunu ortaya koymaktadır, ancak türetkenlik derecesi türetken olma ve olmama arasındaki keskin bir sınıra değil, bir derecelendirmeye dayanmalıdır (Uzun, 2006, s. 90). Bu çalışma, temelde BILGIÇ $C^{l}$, ÇALGIÇ ve YARGIÇ sözcükbirimlerinde alanyazındaki $\{-g(A / I) C ̧\}$ ve $\{-(I / A) \zeta\}$ biçimbirimlerinden hangisi ile türetim gerçekleştirildiği sorusundan ve söz konusu söcükbirimlerde açı bir taban ayrımı belirlemesinin yapılmasındaki güçlükten yola çıkılarak benzer bir sessel çevreye ve işleve sahip olmaları nedeniyle çoğunlukla iç içe ele alınan söz konusu biçimbirimlerin birbirlerine göre dağılımlarını ve türetkenlik derecelerini ortaya çıkarmak amacıyla gerçekleştirilmiştir. Bu amaç doğrultusunda üç ana araştırma sorusu belirlenmiş ve yanıtları aranmıştır:

i. $\{-g A / I \zeta\}\}$ ve $\{-(I / A) \zeta\}$ biçimbirimlerinin eklendikleri ve türettikleri sözcükbirimlerin sözlüksel ulamı nedir?

ii. $\{g A c ̧\},\{g I c\}$ ve $\{-(I / A) \zeta\}$ biçimbirimleri iç içe ele alınmak yerine ayrı biçimbirimler olarak $\mathrm{m}$ incelenmelidir, eğer ayrı biçimbirimler olarak alınmalılarsa $\{g A \mathcal{C}\}, \quad\{g I \mathcal{C}\}$ ve $\{-(I / A) \mathcal{c}\}$ biçimbirimlerinin türetkenlik ölçeğindeki konumları ne olmalıdır?

iii. BILGGIÇ, ÇALGIÇ ve YARGIÇ sözcükbirimleri (E)ylem tabanı üzerine $\{-g I / A c ̧\}$ biçimbirimi eklenmesiyle mi yoksa (A)d türetim biçimbirimi $\{-g I$ I'nın üzerine $\{-(I / A) \zeta\}$ eklenmesiyle mi türetilmiştir?

\footnotetext{
1 Sözcükbiçimler küçükçül biçimde yazılırken sözcükbirimlerin yazımı için büyükçül biçim tercih edilmektedir (Uzun, 2006, s.18-19), bu nedenle çalışmamızda bulguları içeren çizelgeler dışında sözü edilen tüm sözcükbirimler için büyükçül yazım kullanılmaktadır.
} 
$\mathrm{Bu}$ araştırma sorularının yanıtlanması için öncelikle Türkçede türetim, türetkenlik derecesi, türetkenlik ölçeği, gibi kavramlar, Türkçede türetim ve türetim biçimbirimleri, ve $\{-g A / I c ̧\}$ ve $\{-(I / A) c ̧\}$ biçimbirimleri ile ilgili yapılmış çalışmalar betimlenmiştir. Söz konusu çalışmaların denetlenebilmesi ve çalışmamızın hedefini gerçekleştirebilmek için izlenilen yöntem ve veri tabanı tanıtılmıştır. Son olarak veri tabanı çerçevesinde elde ettiğimiz bulgular sergilenmiş, alanyazındaki bulgular da değerlendirilerek tartışılmıştır.

\section{Kuramsal Çerçeve}

Yeni bir sözlüksel birim oluşturmaya türetim denir. Dillerde türetim sürecinin nasıl işlediği dilin tipolojisine bağlıdır. Eklemeli bir dil olan Türkçede türetim, soneklerle gerçekleşmekte, öneklerin kullanımına ise ödünçleme sözcükbirimlerde rastlanmaktadır. Tabana eklenen sonek, çoğu zaman eklendiği tabanın anlamıyla bağlantılı başka bir sözcük türetmekte ve genellikle tabanın sözlüksel ulamını değiştirmektedir (Göksel ve Kerslake, 2005, s. 51); ancak Türkçede her zaman kök ve türemiş sözcükbirim arasında doğrudan bir anlambilimsel bağlantı kurulamadığı (örn. bel-li) veya türetim birleşme (compounding) yoluyla gerçekleştirildiği (örn. arabulucu gibi bir türetim örneğinde, dilde bulucu gibi bir sözcüğün kullanılmaması) için tabanının belirlenmesi sorunlu olabilmektedir. Bu nedenle, belirli bir taban ve ondan türeyen yeni sözcükbirim yerine, biçimbirimlerin eklendikleri bir varsayımsal tabandan (hypothetical base) söz etmek gerekebilmektedir (Uzun, 2004, s.59). Bu noktadan hareketle çalışmamızda Türkçedeki $\{-g A / I c ̧\}$ ve $\{-(I / A) c ̧\}$ türetim biçimbirimlerinin dağılımı, birbirlerine göre ne kadar türetken oldukları ve eklendikleri tabanların sözlüksel ulamları açısıdan incelenmekte ve türetkenlik ölçeğinde olası konumlanışları tartışılmaktadır. Türkçede türetimden söz edebilmek için öncelikle türetkenlik derecesi ve türetkenliği etkileyen etmenlerden kisaca söz edelim.

Bir biçimbirimin türetenlik derecesi söz konusu biçimbirimin ne kadar sık sözcükbirim türettiğine ve bu sözcükbirimlerin konuşucular tarafindan anlaşılabilirliğine bağlıdır. Bir biçimbirim ne kadar çok türetim yapıyorsa tahmin edilebilirliği, dolayısıyla türetkenlik derecesi o kadar yüksek olmakta, bu nedenle bu biçimbirimin oluşturduğu türetimler için ayrı bir sözlük girdisine gereksinim duyulmamaktadır. Kısıtlı bir alanda türetim yapan biçimbirimlerin ise tahmin edilebilirliklerinin düşük oluşu nedeniyle türetkenlik dereceleri düşük olmaktadır (Haspelmath, 2010, s. 115). Buna karşın Uzun (2006, s. 90) bir biçimbirimin türetkenlik derecesine o biçimbirimin yaptığı türetimlerin sayısına bakarak karar verilemeyeceğini ve bir alanda (örn. ad türetme) daha türetken olan biçimbirimin bir başka alanda karşılaştırıldığı diğer biçimbirimden daha az türetkenlik sergileyebileceğini öne sürmektedir. Benzer bir biçimde Haspelmath (2010) da biçimbirimlerin türetken veya türetken 
olmayan biçiminde keskin bir ayrıma tabi tutulmasındansa, birbirlerine göre türetkenlik derecelerinin ortaya konduğu bir türetkenlik ölçeğinde konumlandırılmalarının daha akla yatkın olduğunu savunmaktadır. Haspelmath'ın (2002, s. 42) türetkenlik ölçeğinde bu durum açık bir biçimde şöyle görülmektedir:

Grafik 1 - Türetkenlik Ölçeği

\begin{tabular}{|c|c|c|c|c|c|c|c|}
\hline $\begin{array}{l}\text {-ness } \\
\text { (goodness) }\end{array}$ & $\begin{array}{l}\text {-ize } \\
\text { (globalize) }\end{array}$ & $\begin{array}{l}\text { mis- } \\
\text { (misrepresent) }\end{array}$ & $\begin{array}{l}\text {-ee } \\
\text { (invitee) }\end{array}$ & $\begin{array}{l}\text {-eer } \\
\text { (profiteer) }\end{array}$ & $\begin{array}{l}\text {-al } \\
\text { (refusal) }\end{array}$ & $\begin{array}{l}\text {-th } \\
\text { (warmth) }\end{array}$ & $\begin{array}{l}\text {-ter } \\
\text { (laughter) }\end{array}$ \\
\hline
\end{tabular}

Grafik 1'de sergilendiği gibi türetkenlik ölçeğinde İngilizcedeki türetim biçimbirimlerinin kimileri, birbirlerine göre daha az veya daha çok türetim yapmaları ve sözlükte girdi olarak düzgülenip düzgülenmeme olasılıkları ölçüt alınarak konumlandırılmaktadır. Türkçede de türetim biçimbirimlerini türetim alanları ve sıklıkları değerlendirilerek birbirlerine göre bir türetim ölçeğinde konumlandırmak mümkündür. Bu noktada çalışmamız, inceleme nesnemiz olan biçimbirimlerin türetkenlik ölçeğinde birbirlerine göre konumlanışlarının saptanması açısından özgün bir kaynak niteliği taşımaktadır.

Türetkenlik konusunda bir başka yaklaşım ise türetkenliğin geçmişte faydalılık (profitability) ve işlerlik (availability) olarak ikiye ayrılması ve bir biçimbirimin geçmişte yapılan türetimlerle yeni türetimler yapmaya olan yatkınlığının ayrı ayrı incelenmesi gerektiğidir. Bu yaklaşım, bir biçimbirimin geçmişte çok sayıda türetim yapmış olmasının onun, yeni türetimler yapmaya yatkın olduğu anlamına gelmediğini savunmaktadır. Çalışmamızda, araştırma nesnemiz olan biçimbirimlerin türetkenliği kullandığımız veri tabanı doğrultusunda faydalılık açısından ele alınmıştır. Benzer bir biçimde, bir sözcükbirimin türetkenliği incelenirken çoğunlukla ele alınan türetim sıklığının da tür sıklığı (type frequency) ve türce sıklığı (token frequency) olarak iki ayrı başlık altında ele alınması gerektiği belirtilmiştir. Tür sıklığı, bir biçimbirimin belli bir bütünce içinde yaptığı toplam türetimlerin sayısıyken, türce sıklığıbir türetimin belli bir bütünce içinde tekrarlanma sıklığı olarak tanımlanmaktadır (Bauer, 2003, s. 47). Çalışmamızda incelenen biçimbirimlerle yapılan türetimlerin tür sıklığı değerlendirilmiştir. Örneğin Çizelge (2)'de sergilendiği üzere Türkçede $\{-g I c ̧\}$ biçimbiriminin tür sıklığ 11 'ken, içinde $10 \mathrm{kez} D A L G I C ̧$ sözcükbirimi geçen bir metinde aynı biçimbirimle yapılan başka bir türetim yoksa $\{-g I c ̧\}$ biçimbiriminin türce sıklığı 10'dur. Aronoff (1976, s. 36)'da ise, tür sıklığı ve türetkenlik arasında ise dolaylı bir ilişki olduğu türetkenliğin ölçülmesi için bir biçimbirimin türettiği sözcükbirimlerin, türetebileceği olası sözcükbirimlere oranının değerlendirildiği yöntemler kullanılmasının önerildiği görüşler olduğunu; 
ancak, bu yaklaşımın bir biçimbirimin yapabileceği olası türetimlerin sayısının öngörülmesinin türetimi kısıtlayan etmenlere karşın pek olası olmadığı yönünde eleştirildiği belirtilmiştir. Türkçede türetim sürecinin işletimi sırasında altbiçimciklenmeyi etkileyen ana etmen ses uyumudur. (örn. $\{s \ddot{u} z-\}+\{-g A / I c ̧\} \rightarrow\{$ süzgę̧ $\})$ Türkçede ses uyumu ünlü ve ünsüz benzeşmesi olarak iki başlıkta incelenmektedir, ünlü uyumu da kendi içinde artlık/önlük uyumu ve düzlük/yuvarlaklık uyumu olarak ikiye ayrılmaktadır:

Grafik 2 - Türkçedeki Ünlüler ve Türkçenin Ünlü Uyumu

\begin{tabular}{|c|c|c|}
\hline & ön & arka \\
\hline & düz | yuvarlak & düz | yuvarlak \\
\hline dar & {$[y]$} & [u] \\
\hline $\begin{array}{l}\text { yarı dar } \\
\text { geniş ș }\end{array}$ & [e] [ ] & [a] \\
\hline
\end{tabular}

\begin{tabular}{cc}
\hline Tabanın Son Seslemindeki Ünlü & İzleyebilecek Ünlüler \\
\hline /a/ & $/ \mathrm{a} /, / \mathrm{u} /$ \\
/u/ & $/ \mathrm{a} /, / \mathrm{u} /$ \\
$/ \mathrm{o} /$ & $/ \mathrm{a} /, / \mathrm{u} /$ \\
$\mathrm{/u} /$ & $/ \mathrm{a} /, \mathrm{u} /$ \\
$/ \mathrm{i} /$ & $/ \mathrm{e} /, / \mathrm{i} /$ \\
$\mathrm{le} /$ & $/ \mathrm{e} / \mathrm{i} /$ \\
$/ \varnothing /$ & $/ \mathrm{e} /, / \mathrm{y} /$ \\
$/ \mathrm{y} /$ & $/ \mathrm{e} /, / \mathrm{y} /$ \\
\hline
\end{tabular}

(Göksel ve Kerslake, 2005, s. 9-21)

Grafik (2)'de izleneceği gibi Türkçede artlık/önlük uyumu tabanın son seslemindeki ünlünün art veya ön ünlü olmasına göre taban üzerinde düzgülenen biçimbirimin ünlüsünün/ünlülerinin de art veya ön ünlü olmasını gerektirmektedir (örn. böl-ü̈m). Düzlük/yuvarlaklık uyumunda ise tabanın son seslemindeki ünlünün düz olması taban üzerinde düzgülenen biçimbirimin ünlüsünün/ünlülerinin de düz olmasını, tabanın son seslemindeki ünlünün yuvarlak olması ise, taban üzerinde düzgülenen biçimbirimin ünlüsünün daryuvarlak ya da geniş-düz olmasını (örn. öv-ün-dük) gerektirmektedir (Göksel ve Kerslake, 2004, s. 21). Türkçede çekimsel ve türetimsel süreçlerin gerçekleşmesini sağlayan düzgülenme işlemlerindeki bu türden ses olayları 
kimi zaman biçimbirim saptaması yapılmasını güçleştirebilmektedir (Adalı, 2004, s. 112).

Çalışma nesnemiz olan biçimbirimlerin incelendiği çalışmalarla ilgili yaptığımız alanyazın taraması sonucu Türkçede $\{-g I / A c ̧\}$ ve $\{-(I / A) c ̧\}$ türetim biçimbirimlerinin çoğunlukla artsüremli bir yaklaşımla izlendiği ve bu biçimbirimlerin Türkçenin tarihsel süreci ve lehçeleri içindeki değişimlerinin ortaya konulduğu görülmüş, ancak söz konusu çalışmalarda $\{-g A c ̧\}$ ve $\{-g I c ̧\}$ biçimbirimlerinin hem benzer sessel çevreleri paylaşmaları hem de benzer işlevler taşımaları nedeniyle çoğunlukla iç içe ele alındığı ve $\{-(I / A) c ̧\}$ biçimbiriminin incelenmesinde de benzer bir durumun söz konusu olduğu gözlenmiştir. Örneğin $-e c^{2}$ biçimbirimi Yıldız'ın (2011) çalışmasında $\{-G I c ̧\}$ biçimbiriminin tarihsel süreçte dilbilgiselleşmesiyle açıklanmakta, $A \breve{G} A C ̧$ örneği verilerek $\{-G A c ̧\}$ biçimbiriminin de dilbilgiselleştiği öne sürülmektedir. Banguoğlu'ndan (2004) aktaran Yıldız (2011) aynı çalışmada diğer çalışmalarda sıklıkla (E)ylemden (A)d türettiği söylenen -geç biçimbiriminin kimi zaman S(1fat) da türettiğini belirtmektedir (örn. utangaç). Türkçenin ilk sözlüğü olma özelliğini taşıyan Divan-ı Lügat-ı Türk'deki eşya adları üzerine yapılmış bir çalışmada, -guç ve -gaç biçimbirimleriyle yapılan türetimlere (örn. yoğurguç, kısgaç) yer verilmektedir (Çiftçi ve Yıldırım, 2012). Söz konusu biçimbirimlerin listelendiği kimi çalışmalarda ise, -geç ve -giç biçimbirimlerinin $\mathrm{E}$ tabanından A türeten türetkenlik derecesi düşük biçimbirimler olduğu, $\{-c ̧\}$ biçimbirimininse çoğunlukla dönüşlü E'lere eklendiği (örn. utanç) belirtilmiştir (Kornfilt, 2007). Buna benzer olarak söz konusu biçimbirimlerden -GAC, - GIC ve -(A)C üstyazımıyla söz edildiği gözlenmiştir (Göksel ve Kerslake, 2005, s. 52). Bunun yanında $\mathrm{E}$ tabanından $\mathrm{S}$ ve A türeten $-c ̧$ biçimbiriminin son sesi $/ n /$ olan E'lere eklendiği (örn. sevin-, iğren-, kazan-) ve -gIç biçimbiriminin sonu $/ l /, / n /, / r /$ sesbirimlerinden biriyle biten sözcükbirimler üzerinde düzgülendiği belirtilmiştir (Uzun, 2006, s. 100).

Çalışmamızda, alanyazında yer alan tüm bu incelemeler ışı̆̆ında;

i. $\quad\{-g I / A c ̧\}$ ve $\{-(I / A) c ̧\}$ biçimbirimlerinin birbirleriyle iç içe ele alınıp alınmamasının gereğinin saptanması,

ii. BILG $\dot{I} C ̧, C ̧ A L G I C ̧, Y A R G I C ̧$ sözcükbirimlerindeki taban ayrımı sorununu açıklığa kavuşturulması;

iii. söz konusu biçimbirimlerin eklendikleri tabanların ve türettikleri sözcükbirimlerin sözlüksel ulamlarını ve birbirlerine göre türetimsellik derecelerini betimlenmesi amaçlanmaktadır.

2 Çalışmamızdaki metin içi alıntılarda kullanılan biçimbirimlerin özgün biçimlerine sadık kalınmıştır. 


\section{Veri Tabanı, Veri Toplama Aracı ve Yöntem}

Çalışmamızın araştırma nesnesi $\{-g A / I c ̧\}$ ve $\{-(I / A) c ̧\}$ olarak belirlenmiş ve bu biçimbirimlerle düzgülenen sözcükbirimlerin listelenmesi amacıyla Türkçede sonu /tf/ sesbirimiyle biten sözcükbirimler Dil Derneği'nin Türkçe Sözlük'ü (2012) kullanılarak taranmış -bunun nedeni $\{-(I / A) c ̧\}$ biçimbiriminin [-ç] altbiçimciklenmesi sergiliyor olmasıdır- ve söz konusu biçimbirimlerin Türkçedeki tür sıklıkları saptanmıştır. Çalışmamızın veri tabanı oluşturulurken yapılan alanyazın taramasında Türkçedeki tüm biçimbirimlerin dökümünün yapıldığ bir veritabanına rastlanmamıştır. Bu nedenle, çalışma nesnemiz olan biçimbirimlerle düzgülenmiş sözcükbirimlerin alfabetik sırayla düzenlenmiş tam listesine ulaşmak için sözlük çalışması yapılmış ve resmi nitelik taşıyan Türk Dil Kurumu'na ait Türkçe Sözlük'ün içermesi olası ideolojik bakış açısından kaçınmak adına bağımsız bir kurum olan Dil Derneği'ne ait Türkçe Sözlük seçilmiştir.

Çalışmanın bir sonraki adımında taranan sözcükler içinden herhangi bir türetim biçimbirimi almamış sözcükbirimler ile taranan sözcükbirimler içinde $\{-g A / I c ̧\}$ veya $\{-(I / A) \mathcal{c}\}$ ile türetilmemiş ancak bezer bir sessel çevreye ve anlama sahip $\{-(I) n c ̧\}, \quad\{-m A c ̧\}, b\{-d A / I c ̧\}$ ve $\{-(m) b A c ̧\}$ biçimbirimlerine rastlanmış ve bu biçimbirimlerle düzgülenmiş sözcükbirimler, çalışmanın araştırma nesnesi olmadıkları halde araştırma sonuçlarımızın güvenilirliğinin denetlenebilmesi için çizelgelere dahil edilmeden listelenmiştir. Ardından, çalışma nesnemiz olan $\{-g A / I c ̧\}$ ya da $\{-(I / A) c ̧\}$ biçimbirimleriyle düzgülenen sözcükbirimler, taranan veri tabanı içinden seçilerek birbirlerinden ayrı çizelgelerde listelenmiş, söz konusu biçimbirimler eklendikleri tabanın sözlüksel ulamına göre (A ya da E) biçimbirimlerine ayrılmış, hangi biçimbirimler üzerine eklendikleri ve hangi sözlüksel ulamda sözcükbirim türettikleri (A ya da $\mathrm{S}$ ) incelenmiştir. Bir sonraki aşamada, $\{-g A / I c ̧\}$ ve $\{-(I / A) c ̧\}$ biçimbirimlerinin eklendikleri tabanların ve türettikleri sözcükbirimlerin sözlüksel ulamları, birbirlerine göre türetim sıklıkları ve üzerine eklendikleri çatı biçimbirimlerinin türleri ve sayıları, betimsel istatistiğe dökülerek sıklık çizelgeleri oluşturulmuştur. Elde edilen sayısal verilerin 1şı̆̆ında söz konusu biçimbirimlerin birbirlerine göre türetim dereceleri ve alanları tartışılmış, araştırma sorularımız yanıtlanmıştır.

\section{Bulgular}

Çalışma nesnemiz olan $\{-g A / I c ̧\}$ ve $\{-(I / A) c ̧\}$ biçimbirimlerini incelenebilmesi için yaptığımız incelemede öncelikli olarak taranan, sonu /tf/ sesbirimiyle biten 348 sözcükbirimden $\% 34.7$ yüzdelikteki $121^{3}$ adedi çalışma nesnemizi

3 Çalışmamızın temel sorusunu oluşturan BILGICÇ, ÇALGIÇ ve YARGIÇ söcükbirimlerinin tabanlarının açık bir biçimde belirlenememesi nedeniyle bu üç 
oluşturmaktadır. 180 adedi (\%51.7) herhangi bir türetim biçimbirimi ile düzgülenmemiştir ve çalışmanın alanına girmeyen sözcükbirimler olarak aşağıda listelenmişlerdir:

acıă̆aç, ăgaç, akçaă̆aç, alıç, amaç, angıç, artıuç, aynakıç, badıç, bakraç, başağaç, boduç, bodurağaç, borç, burç, çalakılıç, çeç, çebiç, çekiç, dağlıç, dalkılıç, dinç, dipdinç, dispeç, eksiuç, erinç, erkeç, eşbasınç, evç, eviç, felç, geç, gelgeç, gelmiç, genç, gepegenç, gepgenç, gereç, gildirgıç, girç girç, gizilgüç, gömeç, gönç, güç, güllaç, gümeç, güveç, haç, haliç, hallaç, hamlaç, haraç, harç, hariç, hartuç, havuç, hıncahınç, hınç, hörgüç, hurç, huruç, ırgaç, ihraç, ihtilaç, ihtiyaç, ilaç, imtizaç, inç, ineç, intaç, iskoç, ispenç, imtizaç, istintaç, izaç, kakaç, kakıç, kakınç, karaağaç, kavlıç, kerç, kerebiç, kerpiç, kılaç, kılıç, kıraç, kırbaç, kırç, kırlangıç, kırkağaç, kızılağaç, kızılhaç, kirç, kireç, kokarağaç, konç, kömeç, körağaç, kukuç, kulaç, kulunç, kuyluç, linç, mahreç, malkoç, marpuç, meç, mefluç, melengiç, menengiç, merlengiç, miraç, muhtaç, murç, müheyyiç, mündemiç, münderiç, mürevviç, müziç, oruç, öç, öveç, özdirenç, pabuç, peçiç, penç, piliç, pirinç, potlaç, pöç, puluç, punç, rayiç, revaç, sandviç, saraç, sarnıç, satranç, seç, setliç, siyeç, skeç, smaç, soliç, sonuç, sorguç, streç, suntıraç, süpergüç, sürç, sütlaç, şerç, taç, tedriç, teheyyüç, tehyiç, temevvüç, tepelidalgıç, terviç, turunç, tüveyç, ustunç, üç, üstübeç, üzgeç, vehilharç, verkaç, vinç, yalınkılıc, yalvaç, yamaç, yaslaç, yassıă̆aç, yastaağaç, yeleç, yelengeç, yengeç, yukaç, zangoç, zevç

50 adet (\%14.3) sözcükbirimin ise araştırma nesnemiz olan biçimbirimlerle düzgülenmediği saptanmıştır. Çalışmanın inceleme alanına girmeyen bu 50 sözcükbirimin 18 adedi $\{-(I) n c ̧\}$ biçimbirimiyle, 4 adedi $\{-(m) b A c ̧\}$ biçimbirimiyle, 3 adedi $\{-d I / A c ̧\}$ biçimbirimiyle ve 25 adedi $\{-m A c ̧\}$ biçimbirimiyle düzgülenmiştir. Bu biçimbirimlerle düzgülenen sözcükbirimler aşağıda listelenmiştir:

ayrınç, basınç, bilinç, bulunç, dalınç, duyunç, ezinç, gülünç, ilginç, istenç, istenç, kasınç, korkunç, övünç, sapınç, tapınç, umunç, ürkünç, üzünç, atlambaç, dolambaç, saklambaç, sinenbeç, andaç, andıç, sağdıç, almaç, ayırmaç, bazlamaç, bulamaç, çă̆ırtmaç, demeç, dilmaç, doğramaç, doğrult-maç, dönemeç, eğmeç, emmeç, kanır-maç, karmaç, katışmaç, kazmaç, ovmaç, sı̆̆ırtmaç, soğutmaç, sulamaç, tutmaç, yakmaç, yanıltmaç, yaymaç, yırtmaç

$\{-g A / I c ̧\}$ ve $\{-(I / A) c ̧\}$ biçimbirimlerinin eklendiği sözcükbirimler, bu sözcükbirimlerin sözlüksel ulamları ve anlamları aşağıdaki çizelgelerde

sözcükbirim hem Çizelge (1)'e hem de Çizelge (3)'e dahil edilmiş, sayısal değerler bu durum göz önünde bulundurularak hesaplanmıştır. 
sergilenmektedir. Sözcükbirimlerin anlamlarının da çalışmaya dahil edilmiş olmasının nedeni, ilgili sözcükbirimlerin biçimbirimlerinin izleminde kökün anlamının tahmin edilebilirlik derecesinin düşük olması olasıllı̆ııa karşıllık ortaya çıkabilecek hataları önlemektir. Çizelge (1), Çizelge (2) ve Çizelge (3)'teki verilerin yüzdelik değerleri çalışma nesnemizi oluşturan toplam sözcükbirim sayısı (121 adet) ile çizelgede listelenen ilgili biçimbirimle düzgülenmiş sözcükbirimlerin sayısının birbirine oranıdır.

Çizelge (1)'de $\{-g I c ̧\}$ biçimbirimi ile düzgülenen 11 adet (\%9) sözcükbirim listelenmiş̧tir.

Çizelge 1 - Türkçede Sonu \{-gIç\} Biçimbirimi ile Düzgülenen Sözcükbirimler ve Sözlükteki Anlamlarl

\begin{tabular}{|c|c|}
\hline $\begin{array}{l}\text { Sözcükbirimler } \\
\text { ve Sözlüksel } \\
\text { Ulamları }\end{array}$ & Anlamları \\
\hline aldan-gıç (A) & üzeri ot ya da kumla örtülmüş çukur, tuzak \\
\hline atla-n-gıç (A) & $\begin{array}{l}\text { dereyi geçerken üzerine basıp atlamak için konan büyük } \\
\text { taş, atlama taşı }\end{array}$ \\
\hline baş-lan-gıç (A) & bir eylemin, bir dönemin, bir yaşamın vb.nin ilk bölümü \\
\hline bas-gıç (A) & basamak, baskıç \\
\hline bil-giç (A) & bilgili kimse \\
\hline biz-len-giç (A) & ucu çivili değnek \\
\hline çal-gıç (A) & $\begin{array}{l}\text { kimi telli çalgıların tellerine vurmaya yarar, kuş teleği, } \\
\text { kemik, mika, boynuz vb.den yapılmış çalma aracı, tezene, } \\
\text { mızrap, pena }\end{array}$ \\
\hline dal-gı̨̧ (A) & $\begin{array}{l}\text { genellikle özel donanımla su yüzeyi altında çalışmayı } \\
\text { meslek edinen kimse, balıkadam, kurbağaadam }\end{array}$ \\
\hline pat-lan-gıç (A) & Patlangaç \\
\hline pır-lan-gıç (A) & ses çıkararak dönen topaç \\
\hline yar-giç $c^{4}(A)$ & $\begin{array}{l}\text { ulus adına, yargı yetkisini kullanarak yasaya aykırı } \\
\text { davranışlarda ya da uyuşulmayan işlerde yasayı yerine } \\
\text { getirmekle türeyi gerçekleştirmekle görevli kimse, hâkim }\end{array}$ \\
\hline
\end{tabular}

Çizelge (2)'de $\{-g A c ̧\}$ biçimbirimi ile düzgülenen 18 adet (\%14.8) biçimbirim

4 YARGIÇ sözcükbiriminin kökü \{yar-\} günümüz Türkçesinde aynı anlamda sıklıkla kullanılıyor olmasa da Eyuboğlu (2004, s. 731) YARGIÇ sözcügünün "uçurum, dik bayır" anlamına gelen \{yar-\} tabanı üstüne gıç veya $g u$ ve $c ̧$ ekinin gelmesiyle türediğini belirtmiştir. 
listelenmiştir.

Çizelge 2- Türkçede Sonu \{-gAç\} Biçimbirimi ile Düzgülenen Sözcükbirimler Sözlükteki Anlamları

\begin{tabular}{|c|c|}
\hline $\begin{array}{l}\text { Sözcükbirimler } \\
\text { ve Sözlüksel } \\
\text { Ulamları }\end{array}$ & Anlamları \\
\hline bur-gaç (A) & $\begin{array}{l}\text { bir engelle karşılaşan su ya da hava akıntısının dönerek ve } \\
\text { çukurlaşarak yaptığı çevrinti, ters akıntıların oluşturduğu } \\
\text { dönme, eğrim, çevri, girdap }\end{array}$ \\
\hline çevir-geç (A) & $\begin{array}{l}\text { sac üzerindeki yufkayı çevirmeye yarayan araç } 2 \text {. elektrik } \\
\text { akımını açıp kapama ya da değiştirme işini yapan araç, } \\
\text { şalter }\end{array}$ \\
\hline daya-n-gaç (A) & dayanacak şey \\
\hline del-geç (A) & $\begin{array}{l}\text { mukavva, kâğıt, kayış, maden gibi şeylerde delik açmaya } \\
\text { yarayan araç, zımba }\end{array}$ \\
\hline dola-n-gaç (A) & labirent \\
\hline evir-geç (A) & $\begin{array}{l}\text { sac üzerinde pişirilen yufka ekmekleri çevirmeye yarayan } \\
\text { uzun, yassı tahta araç, pişirgeç }\end{array}$ \\
\hline ilen-geç (S) & sürekli ilenen \\
\hline il-geç (A) & $\begin{array}{l}\text { bir sözcükten sonra gelerek o sözcükle diğer öğeler arasında } \\
\text { ilgi kuran sözcük, edat }\end{array}$ \\
\hline k1s-kaç (A) & $\begin{array}{l}\text { bir şeyi tutup sıkıştırmaya yarayan ataş, kerpeten, pense gibi } \\
\text { araç }\end{array}$ \\
\hline nişan-geç (A) & $\begin{array}{l}\text { düzeltilmiş bir ağaç parçasının kenarına değişik aralıklarda } \\
\text { koşut çizgiler çizmek için, marangozlukta kullanılan el aracı }\end{array}$ \\
\hline pat-lan-gaç (A) & $\begin{array}{l}\text { kamış ya da ağaç dalından yapılıp tabanca gibi ses veren } \\
\text { pistonlu çocuk oyuncağı }\end{array}$ \\
\hline piş-ir-geç (A) & $\begin{array}{l}\text { sac üzerinde pişirilen ekmeği çevirmeye yarayan tahta araç, } \\
\text { evirgeç }\end{array}$ \\
\hline salla-n-gaç (A) & salıncak \\
\hline solu-n-gaç (A) & suda yaşayan hayvanların solunum organı, galsame \\
\hline süz-geç (A) & sıviları süzmeye yarayan araç \\
\hline utan-gaç (S) & $\begin{array}{l}\text { bir toplulukta güvenini yitiren, rahat konuşamayan ve rahat } \\
\text { davranamayan, sıkılgan, mahcup }\end{array}$ \\
\hline üşen-geç (S) & çok üşenen, tembel \\
\hline yüz-geç (A) & $\begin{array}{l}\text { balıklarda ve yüzen memelilerde karın ve göğ̈̈ste çift, sırt, } \\
\text { kuyruk ve anüste tek olarak bulunan, hareketi ve dengeyi } \\
\text { sağlayan organ }\end{array}$ \\
\hline
\end{tabular}


Çizelge (3)'te $\{-(I / A) c ̧\}$ biçimbirimiyle düzgülenen 92 adet (\%76) sözcükbirim listelenmiştir.

Çizelge 3 - Türkçede Sonu \{-(I/A)ç\} Biçimbirimi ile Düzgülenen Sözcükbirimler

\begin{tabular}{|c|c|}
\hline $\begin{array}{l}\text { Sözcükbirimler } \\
\text { ve Sözlüksel } \\
\text { Ulamları }\end{array}$ & Anlamları \\
\hline ak-aç (A) & $\begin{array}{l}\text { bir yerde birikip kalan sıvıları, bir işlem sonunda geriye } \\
\text { kalan artıkları, gereksiz nesneleri dışarıya akıtmak için } \\
\text { kullanılan boru, oluk ya da başka araç }\end{array}$ \\
\hline alna-ç (A) & bir şeyin ön tarafı, ön yüzü, cephe \\
\hline ana-ç (S) & $\begin{array}{l}\text { yavru ya da yemiş yetiştirecek duruma gelmiş olan (hayvan } \\
\text { ya da ağaç) }\end{array}$ \\
\hline $\operatorname{ara}-c^{5}(A)$ & $\begin{array}{l}\text { bir iş yapmakta ya da sonuçlandırmakta yararlanılan nesne, } \\
\text { alet, enstrüman }\end{array}$ \\
\hline $\operatorname{arka-ç~(A)~}$ & 1.ağıl. 2. dağ sırtlarında davarların yatırıldığı düz, kuytu yer \\
\hline ata-ç (S) & atalardan gelen, ata ile ilgili olan \\
\hline avun-ç (A) & acıyı unutturan şey, teselli \\
\hline ayır-aç (A) & $\begin{array}{l}\text { cisimleri, bileşime ya da ayrışıma uğratarak niteliklerini } \\
\text { belirtmede kullanılan özdek, miyar }\end{array}$ \\
\hline ayır-t-aç (A) & ayıraç \\
\hline ayr-aç (A) & $\begin{array}{l}\text { tümce içinde geçen bir sözü metin dışı tutmak için, o sözün } \\
\text { başına ve sonuna getirilen eğmeç biçimindeki işaret, } \\
\text { mutarıza, parantez., } 2 . \text { kitap, defter, dosya yeniden } \\
\text { açıldığında, aranan yerin kolayca bulunabilmesi için sayfa } \\
\text { aralarına konan gereç }\end{array}$ \\
\hline ayrı-ç (A) & yol kavşağı, iki yolun ayrıldığı yer \\
\hline ayta-ç (A) & Konuşmacı \\
\hline baba-ç (A) & erkek kümes hayvanlarının en iri ve yaşlı olanı \\
\hline bağ-la-ç (A) & $\begin{array}{l}\text { eş görevli sözcükleri ya da önermeleri birbirlerine bağlayan } \\
\text { sözcük türü }\end{array}$ \\
\hline bak-aç (A) & dürbün \\
\hline bas-k1-ç (A) & basamak, basgiç \\
\hline
\end{tabular}

\footnotetext{
5 ARAÇ sözcükbiriminin \{ara-\} eylemi üzerine $-I c ̧$ biçimbiriminin gelmesiyle türediğini ve artsüremli bir bakış açısıyla "arama aygıtı" anlamı içerdiği belirtilmiştir (Nişanyan, 2009, s. 33).
} 


\begin{tabular}{|c|c|}
\hline belg & $\begin{array}{l}\text { yazı, çizi ve resimleri telefon bağlantısıyla anında } \\
\text { tıpkıbasım olarak gönderip alabilen elektronik aygıt ve bu } \\
\text { aygıtla gönderilen ya da alınan ileti, belgegeçer, faks }\end{array}$ \\
\hline belir & $\begin{array}{l}\text { bir eylemin, bir önadın ya da bir başka belirtecin anlamını } \\
\text { zaman, yer, ölçü, nitelik, soru kavramları bakımından } \\
\text { etkileyen sözcük, zarf }\end{array}$ \\
\hline benze & $\begin{array}{l}\text { bir uzay aracının karşılaşabileceği çevre etkenlerini yerde } \\
\text { yapay biçimde yaratarak denenmesini sağlayan sistem }\end{array}$ \\
\hline bil-gi-ç (A) & bilgili kimse \\
\hline boş-al- & oşaltmaya yarayan aygıt, hava \\
\hline boz-c & boz renkli \\
\hline büyül-t-eç & 1 büyütme, onlara boyut kazandırma \\
\hline büyi & $\begin{array}{l}\text { odak boyutu birkaç santimetre olan yaklaştırıcı mercek, lup, } \\
\text { pertavsız }\end{array}$ \\
\hline çal-g & $\begin{array}{l}\text { kimi telli çalgıların tellerine vurmaya yarar, kuş teleği, } \\
\text { kemik, mika, boynuz vb.den yapılmış çalma aracı, tezene, } \\
\text { mızrap, pena }\end{array}$ \\
\hline dayan-ç (A) & \\
\hline dik-eç (A) & $\begin{array}{l}\text { k için delik açmaya yarayan çubuk. } 2 . \\
\text { k }\end{array}$ \\
\hline dik-e & $\begin{array}{l}\text { fide dikiminde çukur açmaya ve fide dikmeye yarayan sivri } \\
\text { uçlu araç }\end{array}$ \\
\hline diren & yanma, karşı koyma gücü, mukavemet \\
\hline doğ-c & $\begin{array}{l}\text { zü birdenbire, düşünmeden, içine doğduğu } \\
\text { cal }\end{array}$ \\
\hline domal-1ç (S) & tüm \\
\hline don-dur-aç (A) & derindondurucu, dipfriz \\
\hline dön-dür-eç (A) & $\begin{array}{l}\text { sacda pişirilen yufkayı çevirmeye yarayan tahta ya da } \\
\text { demirden yapılmış firıncı küreği }\end{array}$ \\
\hline dön-eç (A) & $\begin{array}{l}\text { dalgalı akımlı elektrik motor ya da dinamolarında devinimli } \\
\text { bölüme verilen ad, rotor }\end{array}$ \\
\hline dur-aç (A) & $\begin{array}{l}\text { yontu, sütun gibi şeylerin üstüne konduğu parça, ayak, } \\
\text { taban, kaide }\end{array}$ \\
\hline düz-eç (A) & $\begin{array}{l}\text { oir yüzeyin eğiklik derecesini anlamaya yarayan araç, nivo, } \\
\text { esviye aleti }\end{array}$ \\
\hline
\end{tabular}




\begin{tabular}{|c|c|}
\hline edin-ç (A) & $\begin{array}{l}\text { edinilen şey ya da şeyler, müktesebat. } 2 \text {. donuşan ve } \\
\text { dinleyenin dil bilgisi, bireyin tümce üretme ve anlama } \\
\text { yeteneği, karşı edim }\end{array}$ \\
\hline eğ-iç (A) & $\begin{array}{l}\text { yemiş koparırken dalları çekmeye ya da kovandan bal } \\
\text { almaya yarayan araç, gege }\end{array}$ \\
\hline em-eç (A) & su ve karayosunlarının, kökü andıran tutunma organı \\
\hline gönen-ç (A) & 1. bolluk, rahatlık ve varlık içinde iyi yaşama, refah \\
\hline gör-eç (A) & vizör \\
\hline gül-eç (S) & her zaman gülümseyen, gülümser, mütebessim \\
\hline gün-eç (A) & çok güneş alan yer \\
\hline güven-ç (A) & güvenme duygusu, itimat \\
\hline iğren-ç (S) & iğrenme duygusu uyandıran, insanı tiksindiren, müstekreh \\
\hline ilen-ç (A) & ilenmek amacıyla söylenen söz; ilenme, beddua, inkisar \\
\hline im-le-ç (A) & $\begin{array}{l}\text { fiziksel bir olayı kendiliğinden saptayıp çizen aygıt, } \\
\text { kaydedici }\end{array}$ \\
\hline inan-ç (A) & bir düşünceye gönülden bağlı bulunma \\
\hline indük-le-ç (A) & indükleme akımı elde etmeye yarayan aygıt \\
\hline kaldır-aç (A) & $\begin{array}{l}\text { az bir güçle büyük bir yükü kaldırmaya yarayan, bir } \\
\text { dayanma noktası üzerinde devinebilen, inip kalkabilen sert } \\
\text { çubuk, manivela }\end{array}$ \\
\hline kaya-ç (A) & $\begin{array}{l}\text { doğada büyük yer tutan, yerkabuğunun yapı gereci olan bir } \\
\text { ya da birkaç mineralden oluşan kütle }\end{array}$ \\
\hline kayna-ç (A) & $\begin{array}{l}\text { volkan bölgelerinde, belli anlıklarla su ve buhar fişkırtan } \\
\text { sıcak kaynak, gayzer }\end{array}$ \\
\hline kazan-ç (A) & $\begin{array}{l}\text { 1. satılan bir mal, yapılan bir iş ya da harcanan bir emek } \\
\text { karşıllğıında elde edilen para, temettü. 2.yarar, çıkar, getiri, } \\
\text { kâr }\end{array}$ \\
\hline keke-ç (S.) & kekeme \\
\hline kıskan-ç (S) & kıskanma huyunda olan \\
\hline koşa-ç (A) & $\begin{array}{l}\text { tek başına bir anlam taşımayan, birlikte kullanıldı̆̆ı sözcü̆ğe } \\
\text { olumluluk ya da olumsuzluk, sürerlik, kesinlik, güçlü } \\
\text { olasılık kavramları veren -dir eki ya da değil sözcüğ̈̈ }\end{array}$ \\
\hline kuru-t-aç (A) & kurutma kab1 \\
\hline küp-eç (A) & küçük küp, çömlek, kazan \\
\hline orun-ç (A) & rüşvet \\
\hline
\end{tabular}




\begin{tabular}{|c|c|}
\hline ön-le-ç (A) & $\begin{array}{l}\text { araçların bir yerden bir yere geçmesini önlemek için } \\
\text { konulan parmaklık biçimindeki engel, bariyer. } 2 \text { bir b̧ } \\
\text { çarpışmada taşıtın zarar görmesini önlemek için ön ve } \\
\text { arkasına konan parça, tampon }\end{array}$ \\
\hline özen-ç (A) & istek \\
\hline $\begin{array}{l}\text { püs-kür-t-eç } \\
\text { (A) }\end{array}$ & $\begin{array}{l}\text { Sıvıları ve toz durumundaki maddeleri gaz ya da toz } \\
\text { durumunda saçmaya yarayan aygıt, pülverizatör }\end{array}$ \\
\hline sark-aç (A) & $\begin{array}{l}\text { durağan bir nokta çevresinde kendi ağırlığının etkisiyle } \\
\text { salınım yapan devingen katı cisim, rakkas, pandül }\end{array}$ \\
\hline say-aç (A) & $\begin{array}{l}\text { havagazı, elektrik, su gibi şeylerin kullanılan miktarını ya } \\
\text { da mekanik etkilenmeleri ölçen aygıt, saat: Doğalgaz sayacı }\end{array}$ \\
\hline sev-in-ç $(A)$ & istenen ya da hoşa giden bir şeyin olmasıyla duyulan coşku \\
\hline sıra-la-ç (A) & $\begin{array}{l}\text { içinde belli bir sıraya göre kâğgtlar konacak bölmeleri olan } \\
\text { dosya ya da dolap, musannif, cilbent, klasör }\end{array}$ \\
\hline sür-eç (A) & $\begin{array}{l}\text { aralarında birlik olan ya da belli bir düzen içinde yinelenen, } \\
\text { ilerleyen, gelişen olay ya da eylemler dizisi, vetire, proses }\end{array}$ \\
\hline tıka-ç (A) & $\begin{array}{l}\text { herhangi bir şeyin delik ya da ağzını tıkamaya yarayan } \\
\text { nesne }\end{array}$ \\
\hline tiksin-ç (S) & tiksinti verici, tiksindirici \\
\hline tok-aç (A) & çamaşır yıkarken kullanılan, tahtadan, yassı tokmak \\
\hline tok-uç (A) & tokaç \\
\hline top-aç (A) & $\begin{array}{l}\text { çevresine ip sarılıp birden birakılarak ya da kamçı ile } \\
\text { vurularak döndürülen koni biçiminde ucu sivri oyuncak }\end{array}$ \\
\hline top-la-ç (A) & $\begin{array}{l}\text { elektrik dinamolarında, devingen bölümün üzerindeki } \\
\text { iletken devrelerde oluşan akımı toplayıp tek bir devreye } \\
\text { veren aygıt, kolektör }\end{array}$ \\
\hline tut-aç (A) & 1. laboratuvar maşası. 2. Tutacak \\
\hline tut-am-aç (A) & bir şeyin tutulup çekilecek yeri \\
\hline tut-tur-aç (A) & bir şeyin bağlanıp tutturulduğu nesne \\
\hline tüm-le-ç (A) & $\begin{array}{l}\text { 1. tümleyen şey, mütemmim. 2. dilb. genellikle eylemin } \\
\text { anlamını türlü yönlerden tümleyen, herhangi bir ad } \\
\text { durumunda bulunan, ilgeç alan ad ya da tamlama, meful }\end{array}$ \\
\hline ula-ç (A) & $\begin{array}{l}\text { belirteç olarak kullanılan eylem soylu sözcük, bağfiil, } \\
\text { zarffiil, gerundium }\end{array}$ \\
\hline usan-ç (A) & usanma duygusu, bıkma, bıkkınlık, melal \\
\hline utan-ç (A) & utanma duygusu, hicap \\
\hline uy-ar-la-ç (A) & $\begin{array}{l}\text { ayrı büyüklük ve yapılarda olan parçaları bir araya getirmek } \\
\text { için kullanılan bağlama parçası, adaptör }\end{array}$ \\
\hline
\end{tabular}




\begin{tabular}{|c|c|}
\hline üf-le-ç (A) & $\begin{array}{l}\text { 1. kaynak yapımında, metalleri kesme ve eritme } \\
\text { işlemlerinde kullanılan, alev püskürten araç, hamlaç } 2 . \\
\text { laboratuvarlarda yüksek ısı elde edilen araç, hamlaç } 3 \text {. kirli } \\
\text { havayı dışarı atan ya da temiz hava veren aygıt, aspiratör, } \\
\text { vantilatör }\end{array}$ \\
\hline üre-t-eç (A) & herhangi bir mekanik erkeyi elektrik akımına çeviren aygıt, jeneratör \\
\hline üşen-ç (A) & üşenme, üşengeçlik \\
\hline $\operatorname{vur}-a c ̧(A)$ & tokaç \\
\hline yalın-ç (S) & birleşik olmayan, yalnız bir maddeden oluşan \\
\hline yansı-t-aç (A) & yansitici \\
\hline yarg1-ç (A) & $\begin{array}{l}\text { ulus adına, yargı yetkisini kullanarak yasaya aykırı } \\
\text { davranışlarda ya da uyuşulmayan işlerde yasayı yerine } \\
\text { getirmekle türeyi gerçekleştirmekle görevli kimse, hâkim }\end{array}$ \\
\hline yoğun-la-ç (A) & içinde elektrik yükü biriktirilen aygit, kondansatör \\
\hline yön-el-t-eç (A) & $\begin{array}{l}\text { 1. motorlu araçların istenilen doğrultuda yönetilmesini } \\
\text { sağlayan düzen, direksiyon } 2 \text {. çifttekerin ön tekerlek maşası } \\
\text { üstüne bağlanmış, iki elle kullanılan yön değiştirme aracı, } \\
\text { gidon }\end{array}$ \\
\hline yüksel-te-ç (A) & $\begin{array}{l}\text { alçak ya da yüksek frekanslı akımların yararlı etkilerini } \\
\text { artırmaya yarayan araç, amplifikatör }\end{array}$ \\
\hline yürü-t-eç (A) & $\begin{array}{l}\text { yeni yürümeye başlayan çocukların çabuk yürümelerini } \\
\text { sağlayan ara }\end{array}$ \\
\hline
\end{tabular}

$\{-g A c ̧\}, \quad\{-g I c ̧\}$ ve $\{-(I / A) c ̧\}$ ile düzgülenmiş sözcükbirimlerin A tabanından türetilen 29 adedi (\%23.9) ve E tabanından türetilen 92 adedi (\%76) Çizelge (4)'de listelenmiştir.

Çizelge 4 - Türkçede $\{-g A c ̧\},\{-g I c ̧\},\{-(I / A) c ̧\}$ Biçimbirimlerinin Eklendikleri Tabanların Sözlüksel Ulamlarl

\begin{tabular}{llllllll}
\hline & $\begin{array}{c}\text { Ad Tabanı } \\
\text { Üzerinde }\end{array}$ & \multicolumn{5}{c}{ Eylem Tabanı Üzerinde } \\
\hline & & bur-gaç & $\begin{array}{l}\text { çevir- } \\
\text { geç }\end{array}$ & $\begin{array}{l}\text { daya-n- } \\
\text { gaç }\end{array}$ & del-geç & $\begin{array}{l}\text { dola-n- } \\
\text { gaç }\end{array}$ & evir-geç \\
\cline { 3 - 8 }$\{$-gAç\} & nişan-geç & ilen-geç & il-geç & kıs-kaç & pat-lan-gaç & piş-ir-geç & sallan-gaç \\
\cline { 3 - 8 } & & solu-n-gaç & süz-geç & utan-gaç üşen-geç & yüz-geç & \\
\hline \multirow{3}{*}{-gIç\} } & & aldan-gıç & $\begin{array}{l}\text { atla-n- } \\
\text { gıç }\end{array}$ & bas-gıç & baş-lan-gıç & bil-giç & biz-len-giç \\
\cline { 3 - 7 } & & çal-gıç & dal-gıç & $\begin{array}{l}\text { pat-lan- } \\
\text { gıç }\end{array}$ & pır-lan-gıç & yar-gıç & \\
\hline
\end{tabular}




\begin{tabular}{|c|c|c|c|c|c|c|c|c|}
\hline \multirow{12}{*}{$-(\mathrm{I} / \mathrm{A}) \mathrm{c}$} & $\begin{array}{l}\text { aln- } \\
\text { aç }\end{array}$ & ana-ç & aka-ç & ara-ç & avun-ç & ayır-aç & ayr-aç & bağ-la-ç \\
\hline & $\begin{array}{l}\text { arka } \\
\text {-ç }\end{array}$ & ata-ç & bak-aç & $\begin{array}{l}\text { belir-t- } \\
\text { eç }\end{array}$ & $\begin{array}{l}\text { benze-t- } \\
\text { eç }\end{array}$ & boş-al-t-aç & $\begin{array}{l}\text { büyül-t- } \\
\text { eç }\end{array}$ & büyü-t-eç \\
\hline & $\begin{array}{l}\text { ayır- } \\
\mathrm{t} \text {-aç }\end{array}$ & ayrı-ç & dayan-ç & dik-eç & dik-el-eç & diren-ç & domal-1ç & don-dur-aç \\
\hline & $\begin{array}{l}\text { ayta } \\
\text {-ç }\end{array}$ & $\begin{array}{l}\text { baba- } \\
\text { ç }\end{array}$ & dön-dür-eç & dön-eç & dur-aç & edin-ç & eğ-iç & em-eç \\
\hline & $\begin{array}{l}\text { bas- } \\
\text { k1-ç }\end{array}$ & $\begin{array}{l}\text { belge- } \\
\text { c }\end{array}$ & gör-eç & gül-eç & güven-ç & iğren-ç & ilen-ç & im-le-ç \\
\hline & $\begin{array}{l}\text { bil- } \\
\text { gi-ç }\end{array}$ & $\begin{array}{l}\text { boz- } \\
\text { aç }\end{array}$ & inan-ç & $\begin{array}{l}\text { indük- } \\
\text { le-ç }\end{array}$ & kaldır-aç & kayna-ç & kazan-ç & kıskan-ç \\
\hline & $\begin{array}{l}\text { çal- } \\
\text { g1-ç }\end{array}$ & $\begin{array}{l}\text { do } \breve{g}_{-} \\
\text {aç }\end{array}$ & kuru-t-aç & ön-le-ç & özen-ç & $\begin{array}{l}\text { püs-kür-t- } \\
\text { eç }\end{array}$ & sark-aç & say-aç \\
\hline & $\begin{array}{l}\text { düz- } \\
\text { eç }\end{array}$ & $\begin{array}{l}\text { gönen } \\
\text {-ç }\end{array}$ & sev-in-ç & $\begin{array}{l}\text { sira-la- } \\
\text { ç }\end{array}$ & sür-eç & tıka-ç & tiksin-ç & top-la-ç \\
\hline & $\begin{array}{l}\text { gün- } \\
\text { eç }\end{array}$ & $\begin{array}{l}\text { kaya- } \\
\text { ç }\end{array}$ & tut-aç & $\begin{array}{l}\text { tut-tur- } \\
\text { aç }\end{array}$ & tüm-le-ç & ula-ç & usan-ç & utan-ç \\
\hline & $\begin{array}{l}\text { keke } \\
\text {-ç }\end{array}$ & $\begin{array}{l}\text { koşa- } \\
\text { ç }\end{array}$ & uy-ar-la-ç & üf-le-ç & üre-t-eç & üşen-ç & vur-aç & yans1-t-aç \\
\hline & $\begin{array}{l}\text { küp- } \\
\text { eç }\end{array}$ & $\begin{array}{l}\text { orun- } \\
\text { ç }\end{array}$ & & & & & & \\
\hline & $\begin{array}{l}\text { tok- } \\
\text { aç }\end{array}$ & $\begin{array}{l}\text { tok- } \\
\text { uç }\end{array}$ & & & & & & \\
\hline
\end{tabular}

\section{Bulguların Değerlendirilmesi}

Çalışmamızda incelenen sözcüklerin tamamının \%34.7'si (121 adet) $\{-g A / I c ̧\}$ ya da $\{-(I / A) \mathcal{C}\}$ biçimbirimleriyle düzgülenmiştir. Çizelge (1), (2) ve (3)'te sergilendiği üzere $\{-g I c ̧\}$ ile düzgülenen sözcükbirimler bu sayının \%9'unu (11 adet), $\{-g A c ̧\}$ ile düzgülenen biçimbirimler bu sayının \%14.8'ini (18 adet) ve $\{-(I / A) \zeta$ ile düzgülenen biçimbirimler bu sayının \%76'sını (92 adet) oluşturmaktadır. Yukarıdaki verilerde Türkçede $\{-(I / A) \zeta$ biçimbiriminin \{-gA/Iç\} biçimbiriminden 3.1 kat daha çok türetim yaptı̆̆ görülmekte, dolayısıyla $\{-(I / A) \mathcal{c}\}$ biçimbiriminin türetkenlik ölçeğinde daha türetken konuma $\{-g A / I c ̧\}$ biçimbiriminden daha yakın olduğu söylenebilmektedir. 
Grafik 3 - $\{-g A / I c ̧\}$ ve $\{-(I / A) c ̧\}$ Biçimbirimlerinin Birbirlerine Göre Türetim Sayıları ve Yüzdelikleri

\begin{tabular}{cccc}
\hline & $\{-\mathrm{gAç}\}$ & $\{-\mathrm{gIc}\}$ & $\{-(\mathrm{I} / \mathrm{A}) \mathrm{c}\}$ \\
\hline $\begin{array}{c}\text { türetim } \\
\text { say1s1 }\end{array}$ & 18 & 11 & 92 \\
$\begin{array}{c}\text { türetim } \\
\text { yüzdesi }\end{array}$ & $\% 14.8$ & $\% 9$ & $\% 76$ \\
\hline
\end{tabular}

$\{-g A / I c ̧\}$ ve $\{-(I / A) c ̧\}$ biçimbirimleri eklendikleri tabanların sözlüksel ulamına göre incelendiğinde bu biçimbirimlerle türetilmiş toplam 121 sözcükbirimin 92 adedinin (\%76) E tabanından, 29 adedinin (\%23.9) ise A tabanından türetildiği görülmektedir. $\{-g I c ̧\}$ ile yapılan türetimlerin tamamının, $\{-g A c ̧\}$ ile yapılan türetimlerin \%94.4'ünün (17 adet) ve $\{-(I / A) c ̧\}$ ile yapılan türetimlerin \%69.5'inin (64 adet) E tabanı üzerinde olduğu; $\{-g A c ̧\}$ ile yapılan türetimlerin yalnızca 1 adetini $(\% 5.5)$ ve $\{-(I / A)\}\}$ ile yapılan türetimlerin 28 adetinin (\%30.4) A tabanı üzerinde düzgülendiği saptanmıştır.

Grafik 4 - $\{-g A / I c ̧\}$ ve $\{-(I / A) c ̧\}$ Biçimbirimlerinin Eklendikleri Tabanların Sözlüksel Ulamlarl

\begin{tabular}{cccc}
\hline & $\{-\mathrm{gAc}\}$ & $\{$-gIç\} & $\{-(\mathrm{I} / \mathrm{A}) c ̧\}$ \\
\hline ad & 1 & 0 & 28 \\
eylem & 17 & 11 & 64 \\
\hline
\end{tabular}

$\{-\mathrm{gA} / \mathrm{Iç}\}$ ve $\{-(\mathrm{I} / \mathrm{A})$ ç\}biçimbirimleri türettikleri sözcükbirimlerin sözlüksel ulamları incelendiğinde, toplam 121 sözcükbirimin \%89.2'sinin (108 adet) A olduğu, geri kalan \%10.7'sinin (13 adet) ise (S)ıfat olduğu saptanmıştır. \{-gIç\} ile türetilen sözcükbirimlerin tamamının, $\{-g A c ̧\}$ ile türetilen sözcükbirimlerin \%83.3'ünün (15 adet), \{-(I/A)ç\} ile türetilen sözcükbirimlerin ise \%89.1'inin (82 adet) A, $\{-g A c ̧\}$ ile türetilen S'ların 3 adet $(\% 16.6),\{-(I / A) c ̧\}$ ile türetilen S'ların ise 10 adet (\%10.8) olduğu saptanmıştır. Bu bulgular aşağıdaki grafikte daha açık bir biçimde görülebilmektedir:

Grafik 5 - $\{-g A / I c ̧\}$ ve $\{-(I / A) c ̧\}$ Biçimbirimlerinin Türettikleri Sözcükbirimlerin Sözlüksel Ulamları

\begin{tabular}{cccc}
\hline & $\{-\mathrm{gAç}\}$ & $\{$-gIç $\}$ & $\{-(\mathrm{I} / \mathrm{A}) c ̧\}$ \\
\hline ad & 15 & 11 & 82 \\
sifat & 3 & 0 & 10 \\
\hline
\end{tabular}


Yukarıdaki verilere dayanarak $\{-g I c ̧\}$ biçimbiriminin $\mathrm{E}$ tabanından A türeten bir biçimbirim olduğu, $\{-g A c\}$ ve $\{(I / A) c ̧\}^{\prime}$ 'ın ise, çoğunlukla $\mathrm{E}$ tabanından A türettiği ancak bu biçimbirimlerle yapılmış $\mathrm{S}$ türetimlerine de rastlandığı sonucuna ulaşılmıştır. Birinci bölümde Kornfilt'in (2007) $\{-c ̧\}$ biçimbiriminin $\{-n\}$ edilgen çatı üzerine gelebileceğini belirttiğinden söz etmiştik. $\{-g A / I c ̧\}$ ve $\{-(I / A) c ̧\}$ türetim biçimbirimleri eklendikleri tabanın sözlüksel ulamının yanında bir de çatı biçimbirimleri üzerine eklenip eklenmedikleri yönünden incelendiğinde $\{-g A c ̧\}$ 'ın $\mathrm{E}$ tabanına eklenerek türettiği sözcükbirimlerin 4 adedinin $\{-g A c ̧\}$ 'tan önce $(\% 23.5)\{-(I) n\}$ edilgen çatı biçimbirimi, \%5.8'lik dilimi oluşturan 1 adedinin (PATLANGAÇ) \{-lAn\} dönüşlü çatı biçimbirimi, aynı yüzdelik dilime sahip diğer 1 adedinin ise (PIŞ̧IRGEÇ) $\{$-Ir\} ettirgen çatı biçimbirimi aldığı görülmektedir. $\{-g I c ̧\}^{\prime}$ 'n $\mathrm{E}$ tabanına eklenerek türettiği sözcükbirimlerin 4 adedinin (\%36.3) \{-gIç\}'tan önce $\{-l A n\}$ dönüşlü çatı biçimbirimi, \%9'luk dilimi oluşturan 1 adedinin (ATLANGIÇ) ise $\{-(I) n\}$ edilgen çatı biçimbirimi aldığı saptanmıştır. $\{-(I / A) c ̧\}$ 'ın E tabanına eklenerek türettiği sözcükbirimlerin 12 adedinin $(\% 18.7) \quad\{-(I / A) c ̧\}$ 'tan önce $\{-t\}$ ettirgen çatı biçimbirimi, 3 adedinin (\%4.6) $\{$-DIr $\}$ ettirgen çatı biçimbirimi, \% $1.5^{\prime}$ lik yüzdelikte 1 adedinin $(S E V I N C C ̧)$ ise $\{-(I) n\}$ dönüşlü çatı biçimbirimi aldığı saptanmıştır.

Grafik $6-\{-g A / I c ̧\}$ ve $\{-(I / A) c ̧\}$ Biçimbirimlerinden Önce Düzgülenen Çatı Biçimbirimleri

\begin{tabular}{cccc}
\hline & $\{-\mathrm{gAç}\}$ & $\{$-gIç $\}$ & $\{-(\mathrm{I} / \mathrm{A}) c ̧\}$ \\
\hline edilgen & 3 & 1 & 0 \\
ettirgen & 1 & 0 & 15 \\
dönüşlü & 1 & 4 & 1 \\
\hline
\end{tabular}

\section{Tartışma ve Sonuç}

Çalışmamızdaki çözümlemelerden elde edilen verilere göre araştırma sorularımızın yanıtları sırasıyla şöyledir:

i. $\{-g A / I c ̧\}$ ve $\{-(I / A) c ̧\}$ biçimbirimlerinin eklendikleri ve türettikleri sözcükbirimlerin sözlüksel ulam(lar)1 ne(ler)dir?

Çalışmamızda elde edilen bulgular $\{-g A c ̧\}$ ve $\{-(I / A) c ̧\}$ biçimbirimlerinin A veya $\mathrm{E}$ tabanına eklenerek $\mathrm{A}$ veya $\mathrm{S}$ türettiğini (örn. nişan-geç $(\mathrm{A} \rightarrow \mathrm{A})$, burgaç $(\mathrm{E} \rightarrow \mathrm{A})$, ana-ç $(\mathrm{A} \rightarrow \mathrm{S})$, gül-eç $(\mathrm{E} \rightarrow \mathrm{S})),\{-g I c ̧\}$ biçimbiriminin ise yalnızca E kökünden A türettiğini (örn. aldan-gıç) göstermektedir (bkz. Grafik 4). 
ii. $\{-g A c ̧\},\{-g I c ̧\}$ ve $\{-(I / A) c ̧\}$ biçimbirimleri iç içe ele alınmak yerine ayrı biçimbirimler olarak $\mathrm{m}$ incelenmelidir, eğer ayrı biçimbirimler olarak alınmalılarsa bu biçimbirimlerinin türetkenlik ölçeğindeki konumları ne olmalidir?

Elde ettiğimiz bulgular $\{-g A / I c ̧\}$ ve $\{-(I / A) c ̧$ biçimbirimlerinin birbirlerine göre farklı türetim derecelerine sahip olduğunu, dahası $\{-g A c ̧\},\{-g I c ̧\}$ ve $\{-(I / A) c ̧\}$ biçimbirimlerinin türetim alanlarının da kimi zaman farklılık gösterdiğini ortaya koymakta (bkz. Grafik 3 ve Grafik 4) ve bu biçimbirimlerin benzer sessel çevre ve işlevlere sahip olmalarına karşın, birbirlerinden ayrı incelenmeleri gerektiği önvarsayımını güçlendirmektetir.

Çalışmamızda $\{-(I / A) c ̧\}$ biçimbiriminin $\{-g A / I c ̧\}$ biçimibiriminden $\sim 3.1$ kat daha çok türetim yapmış olduğu saptanmış (bkz. Grafik 3) ve $\{-g A / I c ̧\}$ biçimbiriminin Haspelmath'ın (2002) önerdiği türetkenlik ölçeği ekseni üzerinde az türetken, $\{-(I / A) c ̧\}$ biçimbiriminin ise çok türetken bir konuma yerleştirilmesi gerektiği saptanmıştır. Bu bulgu, Bauer'n (2003, s.49) söz ettiği tür sıklığı kavramı açısından değerlendirildiğinde, $\{-(I / A) c ̧\}$ biçimbiriminin $\{-$ $\left.g A / I_{c ̧}\right\}$ biçimbirimine oranla daha çok türetkenlik gösterdiği, yani faydalılığının daha yüksek olduğu yorumu yapılabilir.

Grafik 7- $\{-g A / I c ̧\}$ ve $\{-(I / A) c ̧\}$ Biçimbirimlerinin Türetkenlik Ölçeğindeki Olası Konumu

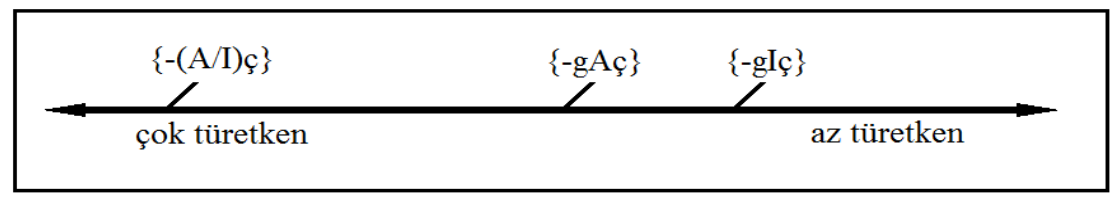

Grafik (7)'de sergilenen olası konumlanışlar doğrultusunda, $\{-(I / A) c ̧\}$ biçimbiriyle yapılan türetimlerin konuşucular tarafından benimsenme olasılığının $\{-g A / I c ̧\}$ biçimbirimiyle yapılan türetimlere göre daha çok olup olmadığ 1 yine konuşucuların anlık oluşumlarının (nonce formation), TDK gibi kurumların sözcük önerilerinin ve sözlüklere yeni girdi olarak alınan sözcüklerin incelenmesiyle denetlenebilir. Bunun yanı sıra, bu bulgularının 1şı̆̆ında çalışmamızın, Türkçede işlek olarak türetim yapan biçimbirimlerle geçmişte türetkenlik sergilemiş biçimbirimlerin ayırt edilebilmesine ve söz konusu biçimbirimlerin türce sıklığına ilişkin çalışmalara katkı sağlayabilecek nitelikte olduğu düşünülmektedir.

iii. $B \dot{I} L G \dot{I} C ̧, C ̧ A L G I C ̧$ ve $Y A R G I C ̧$ sözcükbirimleri E tabanı üzerine $\{-g I / A c ̧\}$ biçimbirimi eklenmesiyle mi yoksa A türetim biçimbirimi $\{-g I\}$ biçimbiriminin üzerine $\{-(I / A) c\}$ eklenmesiyle mi türetilmiştir? 
BILGIÇ, ÇALGIÇ ve YARGIÇ sözcükbirimlerinin tabanlarının saptanması sorunu, elde edilen veriler doğrultusunda bizi iki olası açıklamaya götürmektedir;

1. Yıldız'ın (2011) \{-eç\} biçimbirimini $\{-G l c ̧\}$ biçimbiriminin tarihsel süreçte dilbilgiselleşmesiyle açıkladığı çalışmasındaki $A \breve{G} A C ̧$ örneğine benzer bir biçimde, $\{-g I\}$ biçimbirimiyle türetilen A tabanından sonra eklenen $\{-g I c ̧\}$, dilbilgiselleşerek $\{-(A / I) c\}$ biçimbirimine benzer bir [-ç] altbiçimciklenmesi sergiliyor olabilir.

2. BILGICC, ÇALGIÇ, YARGIÇ sözcükbirimlerinin $\mathrm{E}$ tabanı üzerine doğrudan $\{-g I c ̧\}$ eklenmesiyle türetilmiş olabilir.

$\mathrm{Bu}$ açıklamalardan ikincisi elimizdeki verilere göre daha uygun görünmektedir; çünkü çalışmamızda $\{-g A / I c ̧\}$ ve $\{-(I / A) c\}$ biçimbirimlerinin çoğunlukla $\mathrm{E}$ tabanı üstüne eklendiği saptanmıştır (bkz. Grafik 4). Bu nedenle de BİLGíÇ, $C ̧ A L G I C ̧$ ve YARGIÇ sözcükbirimlerinin $\{-g I\}$ biçimbirimi ile türetilmiş $\mathrm{A}$ tabanı üzerine $\{-g I c ̧\}$ biçimbirimi eklenerek türemiş olması ve bu biçimbirimin Türkçede [c] altbiçimciklenmesi sergileyecek biçimde dilbilgiselleşmesindense, söz konusu sözcükbirimlerin \{bil-\}, \{çal-\}, \{yar-\} E tabanları üzerine doğrudan $\{-g I c ̧\}$ eklenerek türemiş olmasının daha akla yatkın olduğunu düşünülmektedir.

Çalışmamızın sonunda elde edilen bu bulgulardan hareketle, Türkçede $\{-g A c ̧\}, \quad\{-g I c ̧\}, \quad\{-(I / A) c ̧\}$ biçimbirimleri üzerine daha önce yapılmış çalışmalarda ulaşılmış sonuçlar şöyle değerlendirilebilir:

Öncelikle, $\{-g A / I c ̧\}$ ve $\{-(I / A) c ̧\}$ biçimbirimlerinin A veya E tabanı üzerine düzgülenmesinde ya da $A$ veya $S$ türetmesinde dil içi etmenlerin herhangi bir etkisinin olmadığı savlanabilir. Söz konusu biçimbirimlerin türetim sürecinde Uzun'un (2006, s. 98) İngilizcede S'tan A türeten $\{$-ity\} biçimbiriminin $\{-i s h\}$, $\{-y\}, \quad\{$-less $\}$ gibi biçimbirimlerle sıfatlaşmış sözcükbirimlere eklenmemesi örneğindeki gibi bir biçimbirimsel kısıtlamanın söz konusu olduğu gözlenmemiştir. Bunun yanında $\{-g A / I c ̧\}$ ve $\{-(I / A) c ̧\}$ biçimbirimlerinin düzgülenmesinde sesbilimsel bir kısıtlamanın da söz konusu olduğu da saptanmamıştır. Birinci bölümde Uzun'un (2006, s. 100) E'den A ve S türeten -ç biçimbiriminin sonu $/ n /$ sesbirimiyle biten sözcükbirimlere, $\{-g I c ̧\}$ biçimbiriminin de sonu yalnızca $l /, \quad / n /, \quad / r /$ sesbirimleriyle biten sözcükbirimlere eklendiğini savlamış olduğundan söz etmiştik. Ancak, elde ettiğimiz bulgularda karşımıza çıkan ara-ç, im-le-ç, indük-le-ç, kayna-ç, ön-leç, sıra-la-ç, tıka-ç, top-la-ç, ula-ç, uy-ar-la-ç ve üf-le-ç (bkz. Çizelge 3) sözcükbirimleri $\{-(I / A) c ̧\}$ biçimbiriminin sonu $/ n /$ sesbirimiyle bitmeyen sözcükbirimlerde [-ç] altbiçimciklenmesi sergileyebildiğini ve bas-gıç (bkz. Çizelge 1) örneği de $\{-g I c ̧\}$ biçimbiriminin sonu $/ /, / n /$, veya $/ r /$ sesbirimiyle bitmeyen bir sözcükbirim üzerine eklenebileceğini göstermiş ve bu savların 
yeniden gözden geçirilmesi gerekliliğini ortaya koymuştur. $\{-g A / I c ̧\}$ ve $\{-(I / A) c ̧\}$ biçimbirimleriyle türetilen NIŞANGEÇ (bkz. Çizelge 2) dişında her sözcükbirimin Türkçenin ünlü uyumuna (bkz. Grafik 2) uyduğu gözlenmiş, bu sözcükbirimin ünlü uyumuna uymamasının nedeninin de sözcük kökü olan NIŞAN sözcükbiriminin Farsçadan ödünçleme (Eyuboğlu: 2004, s. 495) olması nedeniyle Türkçe ünlü uyumuna uymadığı olduğu belirtilmiştir.

Ayrıca, BILGICC, ÇALGIÇ ve YARGIÇ sözcükbirimlerinde görülen taban ayrımı sorununun Türkçede aynı sessel çevre ve işlevi paylaşan biçimbirimleri üst üst geldiklerinde öbeğe eklenen ilk biçimbirimin anadil konuşucuları tarafindan sezgisel olarak silinmesi olarak (örn. okul-un yönetim oda-sl-sl) tanımlanabilecek sesdizimsel bir kural olan Kekeleme Yasağına (Stuttering Prohibition) benzer bir biçimbirim silinmesiden kaynaklanıyor olabileceği düşünülebilir. Bu bağlamda $\{-g A / I c ̧\}$ ve $\{-(I / A) c ̧\}$ biçimbirimlerinin söz konusu sözcükbirimlerde düzgülenmesinde sesbilimsel etmenlerin etkili olabileceği savlanabilir. Alanyazında bu sesdizimsel kural yalnıza çekim biçimbirimlerini kapsayacak biçimde örnekledirilmiştir (Haig, 2002). Bu durum, $\{-g A c ̧\}$, $\{-g I c ̧\},\{-(I / A) c ̧\}$ biçimbirimlerinin taban ayrımı sorununa ilişkin daha sonra yapılacak çalışmalarda Kekeleme Yasağı'nın türetim biçimbirimleri açısından da incelenmesi gerekliliğini doğurmaktadır. Son olarak, elde ettiğimiz bulgular $\{-g A / I c ̧\}$ ve $\{-(I / A) c ̧\}$ biçimbirimlerinin $\mathrm{E}$ tabanında düzgülendiklerinde $\{-g A c ̧\}^{\prime}$ 'n dönüşlü ve edilgen çatı üzerinde, $\{-g I c\}^{\prime}$ 'ın dönüşlü ve ettirgen çatı üzerinde, $\{-(I / A) c ̧\}^{\prime}$ 'ı da edilgen, ettirgen veya dönüşlü çatı üzerinde türetim yapabildiğini göstermektedir. Böylelikle birinci bölümde söz ettiğimiz Kornfilt'in (1997, s. 448) -geç ve giç biçimbirimlerinin kimi zaman edilgen çatı üzerinde, $-c ̧$ biçimbiriminin ise çoğunlukla dönüşlü çatı üzerinde düzgülendiği savı doğrulanmaktadır. Ancak bizim çalışmamızda bu bulguya ek olara $\{-g A / I c ̧\}$ ve $\{-(I / A) c ̧\}$ biçimbirimilerinin ettirgen ve dönüşlü çatı üzerinde de düzgülenebildiği bulgusu eklenmiştir ve alanyazında söz konusu biçimbirimlerin özellikleri ve eklenme koşulları betimlenirken bu bulguya da yer verilmesi önerilmektedir.

\section{Kaynaklar}

Adalı, O. (2004). Türkiye Türkçesinde Biçimbirimler. İstanbul: Papatya.

Aronoff, M. (1976). Word Formation in Generative Grammar. Massachussetts: The MIT Press.

Bauer, L. (2003). Morphological Productivty. Cambridge: Cambridge University Press.

Çiftçi, M., Yıldırım, T. (2012). Divanü Lugati-t-Türk'te Yer Alan Alet-Eşya Adları.

Turkish Studies - International Periodical For The Languages, Literature and History of Turkish or Turkic. (7)2, 1229-1249.

Eyuboğlu, İ. Z. (2004). Türk Dilinin Etimoloji Sözlügü̈. İstanbul: Sosyal.

Göksel, A., Kerslake, C. (2005). Turkish: A Comprehensive Grammar. Londra ve New York: Routledge. 
Haig, G. (2002). Constraints on Morpheme Repetition in Turkish.

Current Researches in Turkish Linguistics. Gazimagusa: Eastern Mediterranean University Press, 3-12.

Haspelmath, M. (2002). Understanding Morphology. (2. Basim). Londra: Hodder Education.

Haspelmath, M., Sims, A. (2010). Understanding Morphology. (2. Basim). Londra: Hodder Education.

Kornfilt, J. (1997). Turkish (Descriptive Grammar). Londra ve New York: Routledge.

Nişanyan, S. (2009). Sözlerin Soyağacı: Çă̆daş Türkçenin Etimolojik Sözlü̆̆̈̈. İstanbul: Everest.

Uzun, N. E. (2004). Dünya Dillerinden Örnekleriyle Dilbilgisinin Temel Kavramlarl: Türkçe Üzerine Tartışmalar. İstanbul: Papatya.

Uzun, N. E. (2006). Biçimbilim: Temel Kavramlar. İstanbul: Papatya.

Yıldız, H. (2011). Türk Dilinde \{-Gaç\} Ekinin Kaynakları - I. Dil Araştırmaları (8), 115-140. 